\title{
Charcot osteoarthropathy in conservative treatment: clinical and functional results
}

\author{
Jessica Castro de Vasconcelos", Rodrigo Gonçalves Pagnano, Mariangela Ribeiro Resende, Arnaldo Moura Neto, \\ Denise Engelbrecht Zantut Wittmann, Maria Cândida Ribeiro Parisi \\ From 20th Brazilian Diabetes Society Congress \\ Porto Alegre, Brazil. 11-18 November 2015
}

\section{Background}

Charcot neuro-osteoarthropathy $(\mathrm{CA})$ is a rare complication of neuropathy that affects patients who have lost protective sensation, has multiple etiologies and diabetes mellitus is the most prevalent. The CA is progressive degeneration of the affected joints and it is known that, in situations where there is not an adequate intervention, can install the complete destruction of the affected joints, as well as irreversible deformations, which lead to the development of ulcers and high index of amputation. In the consolidation phase, surgical treatment is usually indicated; however, the procedure is not always possible due to clinical limitations of patients, or even surgical difficulty itself. The suropodalic orthosis adapted to the patient may present as an alternative therapy.

\section{Objectives}

To describe sample of patients with Charcot osteoarthropathy Eichenholtz (E) III, Showm (S) C, followed in diabetic foot outpatient clinic of a tertiary hospital in conservative therapy using suropodalic orthosis, evaluating as the main question the walking ability and accomplishment of daily tasks, and the occurrence of ulcer and/or infection.

\section{Materials and Methods}

This is a prospective study, evaluated for the period of 5 years, 14 patients with CA, E III, SC, using suropodalic orthosis. Walking ability and accomplishment of daily tasks were routine annotated using as a tool of the domain 3 of the SF-36 (Medical Outcomes Study 36-Item ShortForm Health Survey), as well as occurrence of ulcer and/ or infection.

* Correspondence: jessicacastrov@gmail.com

\section{Results}

We evaluated 14 patients, $57 \%$ were women and $43 \%$ men, mean age 57.2 years, mean glycosylated hemoglobin $8.2 \%$, with standard deviation of $2.69 \%$. Diabetes average time of 10 years. In the evaluation of items related to function, walking and performing daily activities, we find satisfactory results (Figure 1). During the following five years, none of these patients had an episode of ulcer/or infection in the foot affected.

\section{Conclusion}

Our data suggest that even in advanced stages of AC, when possible, the continued use of suropodalic orthosis may allow the maintenance function and walking ability.

Published: 11 November 2015

doi:10.1186/1758-5996-7-S1-A17

Cite this article as: de Vasconcelos et al:: Charcot osteoarthropathy in conservative treatment: clinical and functional results. Diabetology \& Metabolic Syndrome 2015 7(Suppl 1):A17.

Submit your next manuscript to BioMed Central and take full advantage of:

- Convenient online submission

- Thorough peer review

- No space constraints or color figure charges

- Immediate publication on acceptance

- Inclusion in PubMed, CAS, Scopus and Google Scholar

- Research which is freely available for redistribution 


\begin{tabular}{|c|c|c|c|}
\hline & Yes, very difficult & Yes, difficult bit & Does not hamper in any way \\
\hline n & 14 & 0 & D \\
\hline$B$ & 4 & 6 & 4 \\
\hline$c$ & 0 & 0 & 14 \\
\hline D & 0 & 4 & 10 \\
\hline$E$ & 0 & 0 & 14 \\
\hline $\mathrm{F}$ & 4 & 5 & 5 \\
\hline G & 0 & 11 & 3 \\
\hline $\mathrm{H}$ & 1 & 10 & 3 \\
\hline 1 & 0 & 0 & 14 \\
\hline J & 0 & 0 & 14 \\
\hline
\end{tabular}

A. Vigorous activities such as running, lifting heavy objects, or participating in strenuous sports.

B. Moderate activities such as moving a table, pushing a vacuum cleaner, bowling or playing golf.

C. Lifting or carrying, eroceries

D. Climbing several flights of stairs

E. Climbing one flight of stairs

F. Bending, kneeling, or stooping

G. Waking more than a mile

H. Walking several blocks

I. Walking one block

J. Bathine or dressing yourself

Figure 1 The following items are about activities you might now do during a typical day. 